\title{
Factors Affecting the Adoption and Usage of ICTs within Polish Households
}

\author{
Ewa Ziemba \\ University of Economics in Katowice, Poland
}

ewa.ziemba@ue.katowice.pl

\begin{abstract}
Information and communication technologies (ICTs) encompassing computer and network hardware and software, and so on, as well as various services and applications associated with them, are assuming a growing presence within the modern homestead and have an indelible impact on the professional and everyday life of people. This research aims to explore factors influencing the successful adoption and usage of ICTs within Polish households. Based on prior literature and practical experiences, a framework of success factors is provided. The required data was collected from a survey questionnaire administered to a sample of Polish households to examine this framework and identifies which factors are of greatest importance for the adoption and usage of ICTs within households in Poland. Based on 751 questionnaires the paper indicates that the adoption of ICTs within households is mainly influenced by the economic status of households and cost of ICTs, perceived economic benefits from the usage of ICTs, technological availability and security of ICTs, ICT competences and awareness, as well as satisfaction with the adoption of ICTs. Furthermore, gender, education, and place of residence do not reflect significant differences on the factors. Yet, there are significant differences among the factors that could be attributed to age. Both, policy makers and ICT providers can benefit from the findings with regard to bridging the gap of ICT adoption and use in the Polish households.
\end{abstract}

Keywords: ICTs, households, ICT adoption, ICT usage, success factors, Poland

\section{Introduction}

The turning point for civilization, initiated around the $1960 \mathrm{~s}$, is related to the increasing role of information and communication technologies (ICTs) in creating modern society. This society is referred to as the information society (Berleur, Hercheui, \& Hilty, 2010; Goliński, 2011; Raban, Gordon, \& Geifman, 2011; Webster, 2002). In this society, especially since the end of the 20th century, business, public administration, and everyday life have been deeply influenced by ICTs, and the adoption and usage of ICTs are becoming more widespread. ICTs can contribute toward

Material published as part of this publication, either on-line or in print, is copyrighted by the Informing Science Institute. Permission to make digital or paper copy of part or all of these works for personal or classroom use is granted without fee provided that the copies are not made or distributed for profit or commercial advantage AND that copies 1) bear this notice in full and 2) give the full citation on the first page. It is permissible to abstract these works so long as credit is given. To copy in all other cases or to republish or to post on a server or to redistribute to lists requires specific permission and payment of a fee. Contact Publisher@InformingScience.org to request redistribution permission. changing business methods and models, transforming production and trade, and creating new patterns of learning, work, entertainment, and consumption. The potential of the information society for economic growth and social welfare is enormous (Olla \& Choudrie, 2013), but regrettably it can also be a source of threats and dangers. It can contribute to information and digital exclusion, new social divisions and social stratification, 
economic diversification, loss of privacy, information and computer crimes (Ferro, Dwivedi, GilGarcia, \& Williams, 2010; Luo, Lu, Polgar, \& Cao, 2010; Steyn \& Johanson, 2010).

The information society developed and became more refined over the past 50 years, and began to focus on sustainable development. The move toward the new phase is called the sustainable information society (Berleur et al., 2010; Fuchs, 2009a, 2009b; Schauer, 2003; Servaes \& Carpentier, 2006; Ziemba, 2013; Ziemba, 2016). In this society, ICTs are becoming a key enabler of economic, socio-cultural, political, and environmental sustainability (Berleur et al., 2010; Elliot, 2011; Hilty, 2008, 2009; Melville, 2010; Ziemba, 2015a, 2015b). ICTs cannot play a vital role in poverty alleviation and sustainable development processes unless they are adopted by different groups within society -mainly by enterprises, public administration, and households (Ziemba, 2013, 2015b).

A stream of research to date has focused on exploring the adoption of ICTs from enterprise and public administration perspectives. These studies are mainly concentrated on conducting investigations of ICT employment for supporting decision-making, and creating new business and government models (Boughzala, Janssen, \& Assar, 2014; Dennis, Samuel, \& McNamara, 2014; Grudzewski, Hejduk, Sankowska, \& Wańtuchowicz, 2010; Kowalczyk \& Nogalski, 2007; Tapscott \& Williams, 2012). Some studies identify barriers and determinants for the adoption of ICTs in enterprises and public administration (Ifinedo \& Singh, 2011; Liu, 2011; Olszak \& Ziemba, 2012; Rana, Dwivedi, \& Williams, 2013; Roztocki \& Weistroffer, 2011; Soja, 2010; Yeoh \& Koronios 2010).

While the key issues of ICT adoption within business and public administration are now relatively well-recognized, it is also important to acknowledge that in the information society ICT adoption within households has become prevalent in many forms such as e-commerce, e-government, e-learning, e-health, and e-working (Ziemba, 2016). There are numerous issues worthy of investigation, such as the adoption and usage of emerging ICTs, social exclusion due to unequal and unsuccessful adoption within by different groups of people, and factors influencing the adoption and usage of ICTs.

Factors influencing the adoption and usage of ICTs by household members in the present-day are subjected to scientific research. However, most studies are grounded in the context of welldeveloped economies, e.g., United Kingdom (Choudrie, Vyas, Voros, \& Tsitsianis, 2013; Vyas \& Choudrie, 2013) and Germany (Maier, Laumer, \& Eckhardt, 2011; Niehaves \& Plattfaut, 2011). Researchers also examined factors affecting the adoption and usage of ICTs in households of non-European developing countries, e.g., in Jordan (Abu-Shamaa \& Abu-Shanab, 2015; Dwivedi, AlAlwan, Rana, \& Williams, 2015), Thailand (Kilenthong \& Odton, 2014), and China (Yang, Chen, \& Wei, 2015). The author of this paper, after extensively searching the literature, did not uncover any deep studies about factors affecting the adoption and usage of ICTs within households in less developed European countries, which are called transition economies. European transition economies are the former Eastern Bloc countries, which, since the early 1990s, have been undergoing transition from the command economy model to the free market model. We can identify the leaders of the transition process and the followers (Ziemba, Papaj, Żelazny, \& Jadamus-Hacura, 2015). In the first group there are Poland, the Czech Republic, Hungary, Slovakia, Slovenia, Lithuania, Latvia, Estonia, Croatia, Romania and Bulgaria. The second group includes Belarus, Russia, Georgia, Moldova, Ukraine, Serbia and Montenegro.

This research void is not easily filled, since the body of knowledge for the well-developed and non-European developing economies may not easily be transferred to the transition ones (Soja \& Cunha, 2015). According to Roztocki and Weistroffer (2011), there are meaningful differences in ICT adoption between developed and European transition economies, namely as regards strategy, planning and design, implementation, management, security, economics, sourcing, and impact on 
organizations and society. Soja and Cunha (2015) summarized significant issues that have been established in regard to the use of ICTs in transition economies, i.e., lack of strategic role of ICTs, lower level of ICT use, need for external support in ICT adoption, impact of ICT-related foreign investments, insufficient customer-orientation, inadequate planning .

Since 1989, Poland has gone through a political and economic transformation, which helped it catch up with the most developed economies. Creating and enhancing information society is one of the main transformational aspects in Poland. Currently, the degree of adoption and usage of ICTs in Polish households is still lower than in the most developed European Union countries. However, it is higher than the levels in some countries of the former Eastern Bloc. According to European statistics for 2015, the comparison of some information society indicators for Poland, and well-developed and transition countries is the following (Eurostat, 2015):

- $\quad 75 \%$ of Polish households have Internet access at home; whereas $83 \%$ of households in the EU countries have Internet access at home; furthermore, households in the welldeveloped countries have greater access to the Internet at home than households in the transition countries, e.g., 97\% of households have Internet access at home in Luxemburg and Norway, meanwhile, only $59 \%$ of households have Internet access at home in Bulgaria;

- $27 \%$ of individuals in Poland have never used the Internet; whereas $16 \%$ of the EU individuals have never used the Internet; furthermore, more individuals in the well-developed countries have used the Internet in comparison with individuals in the transition countries, e.g.. only $1 \%$ of individuals have never used the Internet in Norway and Luxemburg, meanwhile, $35 \%$ of individuals have never used the Internet in Bulgaria;

- $26 \%$ of individuals in Poland have never used computers; whereas $16 \%$ of the EU individuals have never used computers; furthermore, more individuals in the well-developed countries have never used computers in comparison with individuals in the transition countries, e.g., only $2 \%$ of individuals have never used computers in Denmark, Luxemburg and Norway, meanwhile, $34 \%$ of individuals have never used computers in Bulgaria;

- $27 \%$ of individuals in Poland use the Internet for interaction with public administration and authorities; whereas $46 \%$ of the EU individuals use the Internet for interaction with public administration and authorities; furthermore, more individuals in the welldeveloped countries use the Internet for interaction with public administration and authorities in comparison with individuals in the transition countries, e.g., $88 \%$ of individuals use the Internet for interaction with public administration and authorities in Denmark, meanwhile, only $11 \%$ of individuals use the Internet for interaction with public administration and authorities in Romania;

- $24 \%$ of individuals in Poland use the Internet for purchasing; whereas $43 \%$ of the EU individuals use the Internet for purchasing; furthermore, more individuals in the welldeveloped countries use the Internet for purchasing in comparison with individuals in the transition countries, e.g., $75 \%$ of individuals use the Internet for purchasing in the United Kingdom, meanwhile, only $8 \%$ of individuals use the Internet for purchasing in Romania; and

- $15 \%$ of individuals in Poland have above basic overall digital skills; whereas $28 \%$ of the UE individuals have above basic overall digital skills; furthermore, more individuals in the well-developed countries have above basic overall digital skills in comparison with individuals in the transition countries, e.g., $56 \%$ of individuals have above basic overall digital skills in Luxemburg, meanwhile, only $9 \%$ of individuals have basic overall digital skills in Romania. 
In general, because of their unique background, the transition countries present very specific challenges that affect how ICTs are adopted and used (Soja \& Cunha, 2015). There are some factors than can influence ICT adoption and usage in transition economies, and these factors may differ from factors for the European well-developed and some developing countries.

To address the aforementioned issues, the objective of this paper is to identify factors influencing the adoption of ICTs within households in Poland. The definition of ICTs employed throughout this paper includes a diverse set of hardware and software used to communicate and to create, disseminate, store, and manage information. They are mainly computers, the Internet, smartphones, and various kinds of e-services, e-products and applications that can be used by household members in professional and everyday life. ICTs are, therefore, understood as a complex "digital households ecosystem".

The remainder of the paper is structured as follows. In the next section, a brief description of existing research on factors affecting the adoption of ICTs within households is presented. Then, the research procedures and tools employed in this study are described and the findings are discussed comprehensively. Finally, the paper concludes by summarizing the key issues from the findings and outlining some related future research.

\section{Literature Review}

The issues of ICT adoption and usage by people in relation to enterprises and public administration have been constantly represented as an attractive area of interest for both academics and practitioners in their endeavors to identify suitable strategies and models which will improve enterprise and public administration performance. Therefore, there has been a large number of studies that explore e-commerce, e-banking, e-health, e-government, and e-learning (Chmielarz \& Zborowski, 2013; Gil-Garcia, 2012; Hamid, Waycott, Kurnia, \& Chang, 2015; Huang \& Benyoucef, 2013; Koohang, Kohun, \& DeLorenzo, 2013; Tarhini, Hone, \& Liu, 2016; Ziemba \& Papaj, 2013). However, the largest number of these studies is focused on examining ICTs from the point of view of enterprise and public administration, e.g., the usage of ICTs for improving relationships with customers. Some studies turn attention to the usage of ICTs by customers, namely the usage of the internet, mobile internet, social media, e-commerce, e-banking, e-health, e-government, and e-learning.

Studies on factors affecting the adoption and usage of ICTs within households are dispersed and fragmentary. They are focused on selected ICTs, e.g., online social networks, internet banking, online shopping, and e-learning. The adoption and usage of ICTs in rural and urban areas are also examined.

For instance, Vyas and Choudrie (2013) explored the adoption, use, and diffusion of online social networks within UK's older population. They identified six theoretical constructs that significantly influence behavioral intention of adoption and usage of online social networks, i.e., hedonic outcomes (providing fun, entertainment, enjoyment), primary influence (friends, family, and relatives recommendations), relative advantage (delivering benefits and improving communication), social outcomes (acquiring friends, widespread respect, popularity), privacy risk (losing control over the privacy of personal information), and technology facilitating conditions (having access to the Internet and computer, and time to use social networks). Furthermore, the research of Choudrie et al. (2013) revealed that age, gender, and education are all associated with adoption rates.

Technology adoption by elderly people in Germany was examined by Maier et al. (2011). According to their study, adopters of social networking are mainly driven by utilitarian outcomes (degree of effectiveness and utility of using PC within households), normative beliefs (friends, family, acquaintances recommendations), perceived ease of use, and fear of technology. Whereas, 
utilitarian outcomes and fear of technology are strong influence factors for non-adopters. Niehaves and Plattfaut (2011) explored Internet adoption in different age-groups. They indicated that the young generation fun is the single most important driver for Internet usage, in the old generation self-efficacy plays the most important role, in the medium age-group self-efficacy, friends' and families' opinion, and applications for personal use form a mixture of influence on behavioral intention.

Dwivedi et al. (2015) indicated that demographic factors (age, income, education, and technology experience) of Jordanian consumers are able to reflect significant differences on customers' usage of internet banking, whereas gender is unable to account for any significant difference in customers' usage of Internet banking. Kesharwani and Bisht (2012) revealed that perceived risk and trust has an impact on internet banking adoption in India. In addition, a well-designed and easy-to-use bank website is a key determinant of internet banking usage.

There are some studies on factors affecting the adoption and usage of e-commerce. Security and privacy are identified among the most important reasons for not using e-commerce in Spain (Pérez-Hernández \& Sánchez-Mangas, 2011). In Jordan, buying from online stores is influenced by the usefulness and ease of use, as well as trust in online stores and trust in internet technology (Abu-Shamaa \& Abu-Shanab, 2015). The research on a business-to-consumer retailer in China also confirmed that trust in web shopping services and perceived integration between web and mobile shopping services positively affect trust in mobile shopping services (Yang et al., 2015).

Additionally, academics have examined factors influencing the adoption and usage of e-learning. Learning motivation, learning style, e-learning system reliability, e-learning system availability, e-learning system security, trust, and incentives have significant effects on the adoption and usage of e-learning in China (Xu \& He, 2014). In another study conducted at the University of Warwick, factors identified as influential to the adoption and usage of e-learning include the institutional infrastructure, staff attitudes and skills, and perceived student expectations (King \& Boyatt, 2015).

The existing research also concerns the adoption and usage of ICTs in rural and urban areas. In Iran, the existence of an ICT center itself, with various funding sources, reinforces adoption regardless of the users' economic status (Moghaddam \& Khatoon-Abadi, 2013). At the same time, the other factors such as individual (age, gender, ICT knowledge and skills, education level, interest towards adopting innovations), social (the users' household attitude toward ICTs as leisure entertainment and working), technological (complexity), and economic are found influential. The findings of research on the usage of ICTs in rural and urban Thailand suggest that household composition, education, wealth, and occupation are key factors determining ICT adaption and usage (Kilenthong \& Odton, 2014).

Some studies have examined the adoption and usage of ICTs in African countries. In most countries, high ICT prices, lack of ICT skills, and lack of relevant e-services with the systems of trust, privacy, and security are identified as the main barrier for those who do have access to the internet (Stork, Calandro, \& Gillwald, 2013). This research confirmed that intergenerational educational strategies and literacy and e-literacy campaigns are needed to enable access to e-services. Likewise, addressing gender equity in access to the internet more sustainably will be achieved only through more equitable access to education for girls. In addition, research conducted in Kenya confirmed that age, income, gender, education level, skills, and marital status influence the adoption and usage of e-mail, the internet, and mobile phones (Ndung'u, Mwololo, \& Mitullahi, 2012).

In summary, the review of the literature presented here reveals that many factors can be examined for their role in driving the adoption and usage of ICTs within households. A summary of the above discussion is presented in Table 1 . 
After extensively searching the literature, any significant studies concerning factors affecting the adoption and usage of ICTs within households in the countries of Central and Eastern Europe were found. This portrays the need for studying these factors in these countries, as well as in Poland. Moreover, studies on the adoption and usage of ICTs within households should take into account the new trend of the information society, namely sustainable development and its main dimensions, i.e., economic, political, socio-cultural, and ecological (Ziemba, 2015b).

Table 1: A summary of the literature regarding factors for the adoption and usage of ICTs within households

\begin{tabular}{|c|c|}
\hline Factors & Support references \\
\hline $\begin{array}{l}\text { Economic factors, namely, economic status and } \\
\text { wealth of households; cost of ICTs; and ICT } \\
\text { funding from the public sector }\end{array}$ & $\begin{array}{l}\text { Kilenthong \& Odton, 2014; Moghaddam \& Khatoon- } \\
\text { Abadi, 2013; Ndung'u, Mwololo, \& Mitullahi, 2012; } \\
\text { Stork, Calandro, \& Gillwald, } 2013\end{array}$ \\
\hline $\begin{array}{l}\text { Technological factors, namely, ICT availabil- } \\
\text { ity; security of ICTs; well-designed and easy- } \\
\text { to-use ICTs; complexity of ICTs; integration of } \\
\text { ICTs; ICT reliability; ICT infrastructure; and } \\
\text { ICT skills }\end{array}$ & $\begin{array}{l}\text { Abu-Shamaa \& Abu-Shanab, 2015; Choudrie, Vyas, } \\
\text { Voros, \& Tsitsianis, 2013; Kesharwani \& Bisht, } \\
\text { 2012; Kilenthong \& Odton, 2014; King \& Boyatt, } \\
\text { 2014; Maier, Laumer, \& Eckhardt, 2011; Moghaddam } \\
\text { \& Khatoon-Abadi, 2013; Ndung'u, Mwololo, \& Mi- } \\
\text { tullahi, 2012; Pérez-Hernández \& Sánchez-Mangas, } \\
\text { 2011; Stork, Calandro, \& Gillwald, 2013; Xu and He, } \\
\text { 2014; Yang, Chen, \& Wei, } 2015\end{array}$ \\
\hline $\begin{array}{l}\text { Social factors, namely, friends, family, and } \\
\text { relatives recommendations; social outcomes } \\
\text { (acquiring friends, widespread respect, popu- } \\
\text { larity); attitudes toward ICTs; incentives; inter- } \\
\text { est towards adopting innovations; perceived } \\
\text { risk, trust, and privacy; fear of technology; } \\
\text { demographic factors of households (age, gen- } \\
\text { der, education, place of residence, and house- } \\
\text { holds composition) }\end{array}$ & $\begin{array}{l}\text { Abu-Shamaa \& Abu-Shanab, 2015; Choudrie, Vyas, } \\
\text { Voros, \& Tsitsianis, 2013; Dwivedi, AlAlwan, Rana, } \\
\text { \& Williams, 2015; Kesharwani \& Bisht, 2012; Kilen- } \\
\text { thong \& Odton, 2014; King \& Boyatt, 2014; Maier, } \\
\text { Laumer, \& Eckhardt, 2011; Moghaddam \& Khatoon- } \\
\text { Abadi, 2013; Ndung'u, Mwololo, \& Mitullahi, 2012; } \\
\text { Niehaves \& Plattfaut, 2011; Pérez-Hernández \& } \\
\text { Sánchez-Mangas, 2011; Stork, Calandro, \& Gillwald, } \\
\text { 2013; Xu and He, 2014; Vyas, \& Choudrie, 2013; } \\
\text { Yang, Chen, \& Wei, 2015 }\end{array}$ \\
\hline $\begin{array}{l}\text { Organizational factors, namely, hedonic } \\
\text { outcomes (fun, entertainment, enjoyment); } \\
\text { some benefits and communication improve- } \\
\text { ment; utilitarian outcomes (degree of effec- } \\
\text { tiveness and utility of using PC within house- } \\
\text { holds); users' expectations }\end{array}$ & $\begin{array}{l}\text { Choudrie, Vyas, Voros, \& Tsitsianis, 2013; King \& } \\
\text { Boyatt, 2014; Maier, Laumer, \& Eckhardt, 2011; } \\
\text { Niehaves, \& Plattfaut, 2011; Vyas, \& Choudrie, } 2013\end{array}$ \\
\hline
\end{tabular}

\section{Research Methodology}

\section{Research Questions and Hypotheses}

This study assumed that ICTs are a diverse set of tools, resources and applications used to communicate and to create, disseminate, store, and manage information. ICTs, therefore, cover hardware (e.g., computers, networks, and telephone equipment) and software (e.g., e-products, eservices, and various applications software).

The research centered upon the following research questions:

Q1: What are the success factors that influence the adoption and usage of ICTs within Polish households? 
Q2: What demographics characteristics of households' members, i.e., gender, age, educational level and place of residence are correlated with success factors for the adoption and usage of ICTs within Polish households?

In order to answer the second research question, the following four research hypotheses were formulated:

H1: Success factors for the adoption and usage of ICTs within Polish households are not significantly different depending on respondents' gender;

H2: Success factors for the adoption and usage of ICTs within Polish households are not significantly different depending on respondents' age;

H3: Success factors for the adoption and usage of ICTs within Polish households are not significantly different depending on respondents' educational level; and

H4: Success factors for the adoption and usage of ICTs within Polish households are not significantly different depending on respondents' place of residence.

\section{Research Procedure}

Research methods included a critical review of the literature, the Delphi study, brainstorming, logical deduction, collaboration, a survey questionnaire, and statistical analysis. The following steps were taken:

- The first step. Factors for the adoption and usage of ICTs within households were identified based on the literature review. This review comprised open access papers, but mainly papers indexed in five bibliographic databases: Ebsco, ProQuest, Emerald Management Plus, ISI Web of Knowledge, and Scopus. The search was conducted using a relevant set of keywords and phrases such as "success factors," "ICT," "adoption," "usage," "people," "household," and "individuals" in all possible permutations and combinations. 32 papers starting in 2010 were provided after the initial search, of which 12 full text papers were unavailable and 6 papers were closely related to other provided papers. Eventually, 14 papers were included in the final study.

- The second step. Factors for the adoption and usage of ICTs within households were identified based on collaboration with the Silesian Centre of Information Society, which is responsible for information society development in the Silesian Region in Poland.

- The third step. The prototype framework of factors for the adoption and usage of ICTs within households was proposed after careful evaluation of the literature findings, practical experiences and brainstorming. That framework included 39 factors in various categories, i.e. economic, socio-cultural, technological, and organizational factors. Simultaneously, the factors can be categorized as related to ICT access, ICT competences, and ICT usage.

- The fourth step. The prototype framework of factors for the adoption and usage of ICTs within households was evaluated and further developed by using the Delphi study. The Delphi study was used due to its principle that decisions from a structured group of individuals are more accurate than those from unstructured groups. Moreover, thanks to the Delphi study, it was possible to include various scientific, as well as ICT and information society experts in this research. Eight experts participated in this study, i.e., four professors of Polish universities conducting studies and empirical research on the information society and four people acting for digital inclusion in Poland. In the last round, the experts evaluated the strength of the influence of particular factors on the adoption and usage of ICTs by answering this question: On a scale of 1 to 5 state to what extent do you agree that the following factors influence the adoption and usage of ICTs by you for achieving sustainable development? A five-point Likert scale was used as follows: 1 - 
strongly disagree, 2 - rather disagree, 3 - neither agree nor disagree, 4 - rather agree, and 5 - strongly agree.

- The fifth step. The final framework of success factors for the adoption and usage of ICTs was provided based on the statistical analysis of the data collected in the last round of the Delphi study. The following techniques for statistical analysis were employed: min, max, mean, median, standard deviation (Std. Dev.), coefficient of variation (CV), and Cronbach's alpha. The final framework included 41 factors that could be categorized into: (1) economic, socio-cultural, technological, and organizational factors, or (2) factors related to ICT access, ICT competences, and ICT usage. All 41 success factors constituting the framework are presented in Table 3.

- The sixth step. The survey questionnaire was elaborated and a five-point Likert scale, described in the fourth step, was used. Consideration of available resources such as time, logistics, manpower and an increased probability of obtaining a substantial sample size led to data collection in the form of an online survey questionnaire. Therefore, applying the CAWI (Computer-Assisted Web Interview) method and employing the Survey Monkey platform, the survey questionnaire was uploaded to the website.

- The seventh step. The sample group was defined. It was composed of 3500 people of different age and gender, with different educational backgrounds, and living in different regions in Poland. To gather a substantial number of respondents, snowball sampling was pursued that involved daily and routine distribution (blog and email posting) of an introduction e-letter and survey-link on surveymonkey.com requesting the co-operation of all ages. The cooperation with the so-called Lighthouse Keepers of Digital Poland was also established. The Lighthouse Keepers are responsible for promoting digital literacy among people from the fifty-plus age group. They are people who went through training and go on to operate in the local community, helping the over-fifties to overcome the barrier of using ICTs. In addition, for increasing response rates the following methods described by Nulty (2008) were used: involve academics (encouraging students and colleagues), push the survey (providing respondents with the survey URL in e-mails sent directly to them), provide frequent reminders, persuading respondents that their responses will be used and the results will be sent to them.

- The eighth step. The data was collected between December 22, 2013 and April 30, 2014. This led to 1037 responses of which 286 responses were incomplete, thereby a final set of 751 usable, correct and complete responses were collected and subjected to further analyses. The obtained response rate to the survey was $21.46 \%$, compared to an average $20 \%$ $47 \%$ response rate for online surveys (Nulty, 2008). The data was stored in two data formats: Microsoft Excel software (MS Excel) and Statistical Package for Social Science (SPSS). MS Excel was used to extract the relevant data and then loaded in SPSS and Statistica to perform the required tests. The results of statistical analysis

- The ninth step. First, reliability was assessed. Cronbach's alpha for each construct was no lower than 0.900 . This shows strong internal consistency and reliability of the scale. Second, the ranking of factors for the adoption and usage of ICTs within households in Poland was provided based on the statistical measures employed in step 5. Third, dependencies between factors for different groups of people were examined. The KolmogorovSmirnov test was used to evaluate the normality assumption. Levene's test was used for evaluating homogeneity of variances. The means of factors in each subgroup of people were normally distributed and the variances of different subgroups were equal; therefore, a t-test and one-way analysis of variance (ANOVA) were used to compare the groups' means. The statistical analysis was made using SPSS and Statistica software. 


\section{Research Findings}

\section{Respondents' Profile and Characteristics}

The summarized features of the respondent profile are described in Table 2. The respondents were diverse in regard to their demographic characteristics, namely gender, age, education level, and place of residence. Only one person from one household participated in the study.

Table 2: Demographic analysis of the data sample

\begin{tabular}{|l|r|r|}
\hline \multicolumn{1}{|c|}{ Demographic profile } & $\begin{array}{c}\text { Number of } \\
\text { respondents }\end{array}$ & Percentage \\
\hline Gender & 491 & $65.38 \%$ \\
\hline female & 257 & $34.22 \%$ \\
\hline male & 3 & $0.40 \%$ \\
\hline n/a & 21 & $2.80 \%$ \\
\hline Age & 87 & $11.58 \%$ \\
\hline over 65 years old (Builders) & 150 & $19.97 \%$ \\
\hline $51-65$ years old (Baby Boomers) & 360 & $47.94 \%$ \\
\hline $36-50$ years old (X) & 99 & $13.18 \%$ \\
\hline $21-35$ years old (Y) & 34 & $4.53 \%$ \\
\hline less than 21 years old (Z) & 507 & $67.51 \%$ \\
\hline n/a & 238 & $31.69 \%$ \\
\hline Level of education & 1 & $0.13 \%$ \\
\hline higher education & 2 & $0.27 \%$ \\
\hline secondary education & 3 & $0.40 \%$ \\
\hline training education & \multicolumn{2}{|l}{} \\
\hline primary education & 499 & $66.44 \%$ \\
\hline n/a & 252 & $33.56 \%$ \\
\hline Place of residence & \\
\hline the Silesian region & \\
\hline other regions &
\end{tabular}

As seen in Table 2, more than half of the respondents (65.38\%) were female, whereas $34.22 \%$ were male. With regard to the respondents' age, this study recommends the age ranges defined by McCrindle (2014). The descriptive statistics revealed that the largest group of respondents was in the age group of 21-35 (47.94\%) followed by the age group of 36-50 (19.97\%). The age group below 21 comprised $13.18 \%$ of the total usable sample size, the age group of 51-65 was $11.58 \%$, and over 65 was $2.80 \%$.

In connection with the level of education, the descriptive statistics show that the most prominent educational level of respondents $(67.51 \%)$ had gained at least a Bachelor's degree. The second main educational level of respondents observed (31.69\%) had acquired a secondary school qualification. The lowest percentage of respondents $(0.4 \%)$ reported that they had other certificates.

In terms of place of residence in Poland, Table 2 depicts that the place of the largest segment of the usable sample was the Silesian region.

\section{Success Factors Framework for the Adoption and Usage of ICTs within Households}

The final framework of success factors for the adoption and usage of ICTs includes 41 factors in various categories (Ziemba, 2016). They are economic (E), socio-cultural (S), technological (T), 
and organizational $(\mathrm{O})$ factors. Moreover, the factors are related to ICT access (a) - reflecting ICT technical and economic accessibilities for households, ICT competences (c) - reflecting ICT competences and awareness of household members, and ICT usage (u) - reflecting actual usage of ICTs within households. The factors for the adoption and usage of ICTs within households and their descriptive statistics are shown in Table 3.

Table 3: Framework of success factors for the adoption and usage of ICTs within households and descriptive statistics of each factor

\begin{tabular}{|c|c|c|c|c|c|c|c|c|c|}
\hline No. & Success factor & 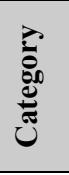 & 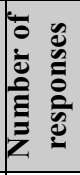 & $\Xi$ & $\sum^{\stackrel{\star}{*}}$ & $\sum_{\Sigma}^{\tilde{\Xi}}$ & 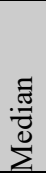 & $\begin{array}{l}\text { Std. } \\
\text { Dev } \\
\text {. }\end{array}$ & $\begin{array}{l}\mathrm{CV} \\
\%\end{array}$ \\
\hline $\mathrm{X} 1$ & Public outlay on hardware, networks, and telecommunica- & E/a & 749 & 1 & 5 & 3.99 & 4 & 0.91 & 22.70 \\
\hline $\mathrm{X} 2$ & $\begin{array}{l}\text { Private outlay on hardware, networks, and telecommunica- } \\
\text { tions }\end{array}$ & $\mathrm{E} / \mathrm{a}$ & 745 & 1 & 5 & 3.97 & 4 & 0.87 & 21.83 \\
\hline $\mathrm{X} 3$ & Competition on ICT market & E/a & 747 & 1 & 5 & 4.18 & 4 & 0.89 & 21.25 \\
\hline $\mathrm{X} 4$ & $\begin{array}{l}\text { Public outlay on e-products and e-services delivered by } \\
\text { enterprises and public administration }\end{array}$ & $\mathrm{E} / \mathrm{a}$ & 743 & 1 & 5 & 3.98 & 4 & 0.94 & 23.69 \\
\hline $\mathrm{X} 5$ & $\begin{array}{l}\text { Private outlay on e-products and e-services delivered by } \\
\text { enterprises and public administration }\end{array}$ & $\mathrm{E} / \mathrm{a}$ & 743 & 1 & 5 & 3.95 & 4 & 0.84 & 21.35 \\
\hline $\mathrm{X} 6$ & Public and private outlay on ICT education for people & $\mathrm{E} / \mathrm{c}$ & 745 & 1 & 5 & 4.16 & 4 & 0.89 & 21.45 \\
\hline $\mathrm{X} 7$ & Outlay on creating ICT competence centre for people & $\mathrm{E} / \mathrm{c}$ & 745 & 1 & 5 & 3.69 & 4 & 0.94 & 25.53 \\
\hline $\mathbf{X 8}$ & Financial situation of people & $\mathbf{E} / \mathbf{a}$ & 751 & 1 & 5 & 4.41 & 5 & 0.80 & 18.14 \\
\hline $\mathbf{X 9}$ & Economic benefits for people arising from ICT adop- & $\mathbf{E} / \mathbf{u}$ & 748 & 1 & 5 & 4.20 & 4 & 0.81 & 19.22 \\
\hline $\mathbf{X 1 0}$ & ICT costs & $\mathbf{E} / \mathbf{u}$ & 750 & 1 & 5 & 4.37 & 5 & $\mathbf{0 . 8 3}$ & 19.12 \\
\hline $\mathrm{X} 11$ & Public outlay on ICT promotion & $\mathrm{E} / \mathrm{u}$ & 748 & 1 & 5 & 3.62 & 4 & 0.95 & 26.39 \\
\hline $\mathrm{X} 12$ & Private outlay on ICT promotion & $\mathrm{E} / \mathrm{u}$ & 748 & 1 & 5 & 3.59 & 4 & 0.96 & 26.81 \\
\hline $\mathrm{X} 13$ & $\begin{array}{l}\text { Differentiation of service and product charges due to pro- } \\
\text { cessing - electronic or traditional }\end{array}$ & $\mathrm{E} / \mathrm{u}$ & 750 & 1 & 5 & 4.03 & 4 & 0.86 & 21.32 \\
\hline $\mathbf{X 1 4}$ & People's awareness of ICTs & $\mathbf{S} / \mathbf{a}$ & 747 & 1 & 5 & 4.28 & 4 & 0.77 & 18.01 \\
\hline $\mathrm{X} 15$ & $\begin{array}{l}\text { Consumers' participation in creating and designing prod- } \\
\text { ucts and services (electronic and non-electronic) - }\end{array}$ & $\mathrm{S} / \mathrm{a}$ & 748 & 1 & 5 & 3.56 & 4 & 0.93 & 26.09 \\
\hline $\mathrm{X} 16$ & $\begin{array}{l}\text { Encouraging people to use ICTs through promotions and } \\
\text { advertising of enterprises and public administration }\end{array}$ & $\mathrm{S} / \mathrm{u}$ & 749 & 1 & 5 & 3.99 & 4 & 0.84 & 21.03 \\
\hline $\mathrm{X} 17$ & Personal mastery & $\mathrm{S} / \mathrm{c}$ & 748 & 1 & 5 & 3.65 & 4 & 0.94 & 25.77 \\
\hline $\mathrm{X} 18$ & New s & $\mathrm{S} / \mathrm{c}$ & 745 & 1 & 5 & 3.93 & 4 & 0.85 & 21.57 \\
\hline $\mathrm{X} 19$ & Competency flexibility & $\mathrm{S} / \mathrm{c}$ & 746 & 1 & 5 & 3.93 & 4 & 0.84 & 21.45 \\
\hline $\mathrm{X} 20$ & Demographic changes & $\mathrm{S} / \mathrm{a}$ & 750 & 1 & 5 & 3.82 & 4 & 1.02 & 26.79 \\
\hline $\mathrm{X} 21$ & $\begin{array}{l}\text { Assuring availability of work, products, services, and } \\
\text { education to individuals at risk of digital and social exclu- }\end{array}$ & $\mathrm{S} / \mathrm{u}$ & 749 & 1 & 5 & 4.01 & 4 & 0.92 & 22.83 \\
\hline $\mathbf{X 2 2}$ & Technological availability of ICTs & $\mathbf{T} / \mathbf{a}$ & 750 & 1 & 5 & 4.49 & 5 & 0.71 & 15.90 \\
\hline $\mathrm{X} 23$ & Availability of innovative ICTs & $\mathrm{T} / \mathrm{a}$ & 747 & 1 & 5 & 4.17 & 4 & 0.82 & 19.64 \\
\hline $\mathbf{X 2 4}$ & Open source software licenses & $\mathbf{T} / \mathbf{a}$ & 749 & 1 & 5 & 4.22 & 4 & 0.87 & 20.62 \\
\hline $\mathrm{X} 25$ & ICT use facilitators (leaders) & $\mathrm{T} / \mathrm{c}$ & 748 & 1 & 5 & 3.78 & 4 & 0.94 & 24.90 \\
\hline $\mathrm{X} 26$ & People's competences of ICTs & $\mathbf{T} / \mathbf{c}$ & 745 & 1 & 5 & 4.29 & 4 & 0.77 & $\mathbf{1 7 . 9 6}$ \\
\hline $\mathrm{X} 27$ & Standardized ICTs & $\mathrm{T} / \mathrm{a}$ & 745 & 1 & 5 & 3.93 & 4 & 0.89 & 22.63 \\
\hline $\mathrm{X} 28$ & $\begin{array}{l}\text { Quality of e-services and e-products delivered by enterpris- } \\
\text { es and public administration }\end{array}$ & $\mathrm{T} / \mathrm{u}$ & 746 & 1 & 5 & 4.17 & 4 & 0.82 & 19.65 \\
\hline $\mathrm{X} 29$ & ICT security & $\mathrm{T} / \mathrm{u}$ & 747 & 1 & 5 & 4.20 & 4 & 0.84 & 20.00 \\
\hline $\mathrm{X} 30$ & ICT trainings and e-trainings & $\mathrm{T} / \mathrm{a}$ & 748 & 1 & 5 & 3.84 & 4 & 0.99 & 25.73 \\
\hline $\mathrm{X} 31$ & $\begin{array}{l}\text { Maturity of e-services delivered by enterprises and public } \\
\text { administration }\end{array}$ & $\mathrm{T} / \mathrm{u}$ & 746 & 1 & 5 & 3.96 & 4 & 0.89 & 22.49 \\
\hline $\mathrm{X} 32$ & Electronic signature & $\mathrm{T} / \mathrm{u}$ & 749 & 1 & 5 & 3.33 & 3 & 1.14 & 34.38 \\
\hline $\mathrm{X} 33$ & E-voting & $\mathrm{T} / \mathrm{u}$ & 749 & 1 & 5 & 3.56 & 4 & 1.12 & 31.35 \\
\hline $\mathrm{X} 34$ & Electronic public consultation & $\mathrm{T} / \mathrm{u}$ & 747 & 1 & 5 & 3.54 & 4 & 1.10 & 31.02 \\
\hline
\end{tabular}




\begin{tabular}{|c|c|c|c|c|c|c|c|c|c|}
\hline No. & Success factor & 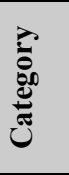 & 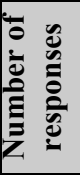 & $\Xi$ & 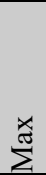 & $\sum_{\tilde{\Xi}}^{\tilde{\Xi}}$ & 点 & $\begin{array}{l}\text { Std. } \\
\text { Dev } \\
\text {. }\end{array}$ & $\begin{array}{l}\mathrm{CV} \\
\%\end{array}$ \\
\hline $\mathrm{X} 35$ & Legal support for the adoption of ICTs & $\mathrm{O} / \mathrm{a}$ & 751 & 1 & 5 & 3.78 & 4 & 0.92 & 24.41 \\
\hline $\mathrm{X} 36$ & New model of education & $\mathrm{O} / \mathrm{c}$ & 748 & 1 & 5 & 3.91 & 4 & 0.92 & 23.59 \\
\hline $\mathrm{X} 37$ & Remote performance of official duties & $\mathrm{O} / \mathrm{u}$ & 744 & 1 & 5 & 4.10 & 4 & 0.87 & 21.18 \\
\hline $\mathrm{X} 38$ & $\begin{array}{l}\text { Obligatory ICT usage at schools, universities, workplaces, } \\
\text { in contacts with authorities }\end{array}$ & $\mathrm{O} / \mathrm{u}$ & 750 & 1 & 5 & 4.13 & 4 & 0.89 & 21.57 \\
\hline $\mathbf{X 3 9}$ & Need to make people's lives easier & $\mathbf{O} / \mathbf{u}$ & 748 & 1 & 5 & 4.47 & 5 & 0.77 & $\mathbf{1 7 . 2 4}$ \\
\hline $\mathbf{X} 40$ & $\begin{array}{l}\text { People's satisfaction with e-products and e-services } \\
\text { delivered by enterprises and public administration }\end{array}$ & $\mathbf{O} / \mathbf{u}$ & 750 & 1 & 5 & 4.39 & 5 & 0.76 & 17.27 \\
\hline $\mathrm{X} 41$ & Globalization & $\mathrm{O} / \mathrm{u}$ & 744 & 1 & 5 & 4.05 & 4 & 0.89 & 22.01 \\
\hline
\end{tabular}

The calculated means for 41 success factors are in the range from 3.33 to 4.49 , using a five-point Likert scale. The means of 19 factors exceed 4.00. For five factors the medians achieve the highest value (namely 5.00), and the means for those factors are higher than the means for the other factors.

\section{Differences in Success Factors for the Adoption and Usage of ICTs Depending on Respondents' Demographics Characteristics}

The first hypothesis tested whether there are no significant differences between the factors for the adoption and usage of ICTs depending on gender. The difference between the means of factors of two independent samples, i.e., male and female was evaluated by an independent samples t-test. The $t$-test result $(\mathrm{t}=0.990 ; \mathrm{p}=0.325)$ did not show any significant difference in the mean values. The Pearson correlation value ( $\mathrm{r}=0.943 ; \mathrm{p}=2.94 \mathrm{E}-20)$ showed a high correlation between factors for the adoption and usage of ICTs by males and females.

The second hypothesis tested whether there are no significant differences between the factors for the adoption and usage of ICTs depending on age. The difference between the means of factors of five independent samples, i.e., less than 21 years old, 21-35 years old, 36-50 years old, 51-65 years old, over 65 years old was evaluated by the ANOVA test. The one-way ANOVA test revealed a statistically significant main effect $(\mathrm{F}=3.85 ; \mathrm{p}=0.0049)$ indicating that not all five groups of people resulted in the same evaluation of factors. Post-hoc comparisons using the Tukey HSD (Honest Significant Difference) test indicated that the means of factors for people in the age group of less than 21 years old were significantly lower than the means of factors for people in the age group of 51-65 years old. The means and standard deviations of factors for all groups are shown in Table 4 . There was no statistically significant difference in the mean scores between Group 1 and Group 2.

Table 4: Basic statistics of factors for the adoption and usage of ICTs in various age groups of people

\begin{tabular}{|l|c|c|c|c|}
\hline \multicolumn{1}{|c|}{ Age group of people } & Mean & Std. Dev. & Group 1 & Group 2 \\
\hline less than 21 years old & 3.879 & 0.311 & $* * * *$ & \\
\hline 21-35 years old & 3.964 & 0.271 & $* * * *$ & $* * * *$ \\
\hline over 65 years old & 4.002 & 0.309 & $* * * *$ & $* * * *$ \\
\hline 36-50 years old & 4.011 & 0.320 & $* * * *$ & $* * * *$ \\
\hline 51-65 years old & 4.138 & 0.394 & & $* * * *$ \\
\hline
\end{tabular}


The third hypothesis tested whether there are no significant differences between the factors for the adoption and usage of ICTs depending on the level of education. The difference between the means of factors of two independent samples, i.e., higher and secondary educational levels was evaluated by an independent samples t-test. The $\mathrm{t}$-test result $(\mathrm{t}=-1.812 ; \mathrm{p}=0.074)$ did not show any significant difference in the mean values. The Pearson correlation value $(r=0.918 ; \mathrm{p}=2.96 \mathrm{E}-17)$ showed a high correlation between factors for the adoption and usage of ICTs for people with secondary and higher education.

The fourth hypothesis tested whether there are no significant differences between the factors for the adoption and usage of ICTs depending on the place of residence. The difference between the means of factors of two independent samples, i.e., the Silesian region and other regions of Poland was evaluated by an independent samples $t$-test. The $t$-test result $(t=-1.534 ; p=0.129)$ did not show any significant difference in the mean values. The Pearson correlation value $(\mathrm{r}=0.901$; $\mathrm{p}=9.63 \mathrm{E}-16$ ) showed a high correlation between factors for the adoption and usage of ICTs for people living in the Silesian region and other regions of Poland.

\section{Critical Success Factors for the Adoption and Usage of ICTs within Households}

The results of statistical analysis allow the recommendation of factors that are of greatest importance for the adoption and usage of ICTs within households in Poland. These factors can be called the critical success factors (CSFs) (Rockart, 1979). They are the areas that should require a primary focus in order to achieve the most satisfying results of ICT adoption and usage. They concentrate on the most important areas and delineate what is to be achieved and how it will be achieved. Their identification can help households, and also governments and enterprises to know exactly what is most important for the successful adoption and usage of ICTs within households.

Ten CSFs for the adoption and usage of ICTs within households were identified on the basis of their statistics. The means of these factors are the highest of the 41 factors, and are equal to or greater than 4.20. Additionally, they exceed the mean of all 41 factors, which is 3.99. The medians of the first five factors are all 5, and they are the highest of all 41 factors. The medians of the remaining five factors are 4 . For the five factors, the value that occurs most frequently in the population is 5 . For the remaining five factors the value that occurs most frequently in the population is 4 , but there is a small differentiation between appearance of the numbers 4 and 5 in a set of data.

The CSFs for the adoption and usage of ICTs within households in Poland include (they are marked in bold in Table 3):

- Financial situation of individuals (X8) - the capabilities of financing the purchase and usage of ICTs (e.g., computers and mobile devices, various software, e-services and eproducts, the internet) and improving ICT competences;

- ICT costs (X10) - low costs of purchasing and servicing hardware and software, ICT training, and education;

- Economic benefits for people arising from ICT adoption (X9) - cost savings, time savings, savings in various materials, and greater efficiency in performing housework and professional duties;

- Technological availability of ICTs (X22) - computers, tablets, smartphones, broadband and next generation access networks (NGA/NGN), applications for computers and mobile devices, e-service, e-products, etc. that respond to people needs;

- Open source software licenses (X24) - software freely used, modified, shared, and quite easily adopted by people; 
- ICT security (X29) - ensuring of security during ICT usage, e.g., masked passwords, encrypted connections with the web, anti-virus software, firewalls, etc.;

- ICT competences of people (X26) - at least ICT competences required to use ICTs for carrying out simple personal and professional tasks;

- People's awareness of ICTs (X14) - people's awareness of the usage of ICTs in life;

- Need to make people's lives easier (X39) - ICTs can make some tasks easier, e.g., shopping, learning, dealing with official matters, and communicating with family and friends; ICTs can have positive effects on well-being and make people happier; and

- People's satisfaction with e-products and e-services delivered by enterprises and public administration (X40) - satisfied people usually purchase e-products and e-services again and again, and additionally they tell other people about their experiences and encourage them to adopt ICTs and use e-products and e-services.

The collected data indicates that two organizational factors connected with ICT usage play a critical role in the adoption and usage of ICTs within households in Poland. Three factors are directly related to the economic issues of ICT access and usage. Among the ten CSFs, four factors are directly related to technological issues of ICT access, competences, and usage. Success in the adoption and usage of ICTs also requires the appropriate socio-cultural environment.

\section{Critical Success Factors for the Adoption and Usage of ICTs within Households Depending on Respondents' Demographics Characteristics}

The CSFs for the adoption and usage of ICTs within households depending on gender are presented in Table 5.

Table 5: CSFs for the adoption and usage of ICTs depending on gender

\begin{tabular}{|c|c|c|c|c|c|c|c|c|c|}
\hline No. & Critical Success factor & 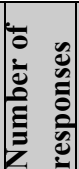 & $\sum_{\Sigma}^{\Xi}$ & 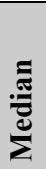 & No. & Critical Success factor & 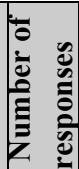 & $\sum^{\Xi}$ & 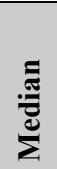 \\
\hline \multicolumn{5}{|c|}{ Female } & \multicolumn{5}{|c|}{ Male } \\
\hline X39 & $\begin{array}{l}\text { Need to make people's lives } \\
\text { easier }\end{array}$ & 489 & 4.50 & 5 & $\mathbf{X} 22$ & $\begin{array}{l}\text { Technological availability of } \\
\text { ICTs }\end{array}$ & 256 & 4.50 & 5 \\
\hline $\mathbf{X} 22$ & $\begin{array}{l}\text { Technological availability of } \\
\text { ICTs }\end{array}$ & 491 & 4.48 & 5 & X39 & $\begin{array}{l}\text { Need to make people's lives } \\
\text { easier }\end{array}$ & 256 & 4.42 & 5 \\
\hline X40 & $\begin{array}{l}\text { People's satisfaction with e- } \\
\text { products and e-services deliv- } \\
\text { ered by enterprises and pub- } \\
\text { lic administration }\end{array}$ & 491 & 4.45 & 5 & $\mathrm{X} 14$ & People's awareness of ICTs & 257 & 4.37 & 4 \\
\hline X8 & Financial situation of people & 491 & 4.44 & 5 & X8 & Financial situation of people & 257 & 4.33 & 5 \\
\hline $\mathbf{X 1 0}$ & ICT costs & 491 & 4.40 & 5 & $\mathbf{X 1 0}$ & ICT costs & 256 & 4.30 & 5 \\
\hline $\mathbf{X 2 6}$ & People's competences of ICTs & 488 & 4.33 & 4 & $\mathbf{X} 40$ & $\begin{array}{l}\text { People's satisfaction with e- } \\
\text { products and e-services de- } \\
\text { livered by enterprises and } \\
\text { public administration }\end{array}$ & 256 & 4.29 & 4 \\
\hline $\mathbf{X 1 4}$ & People's awareness of ICTs & 487 & 4.24 & 4 & $X 3$ & Competition on ICT market & 255 & 4.26 & 4 \\
\hline$X 29$ & ICT security & 488 & 4.24 & 4 & $\mathbf{X} 24$ & $\begin{array}{l}\text { Open source software licens- } \\
\text { es }\end{array}$ & 256 & 4.23 & 4 \\
\hline$x 9$ & $\begin{array}{l}\text { Economic benefits for people } \\
\text { arising from ICT adoption }\end{array}$ & 488 & 4.23 & 4 & $\mathbf{X} 26$ & People's competences of ICTs & 254 & 4.22 & 4 \\
\hline
\end{tabular}




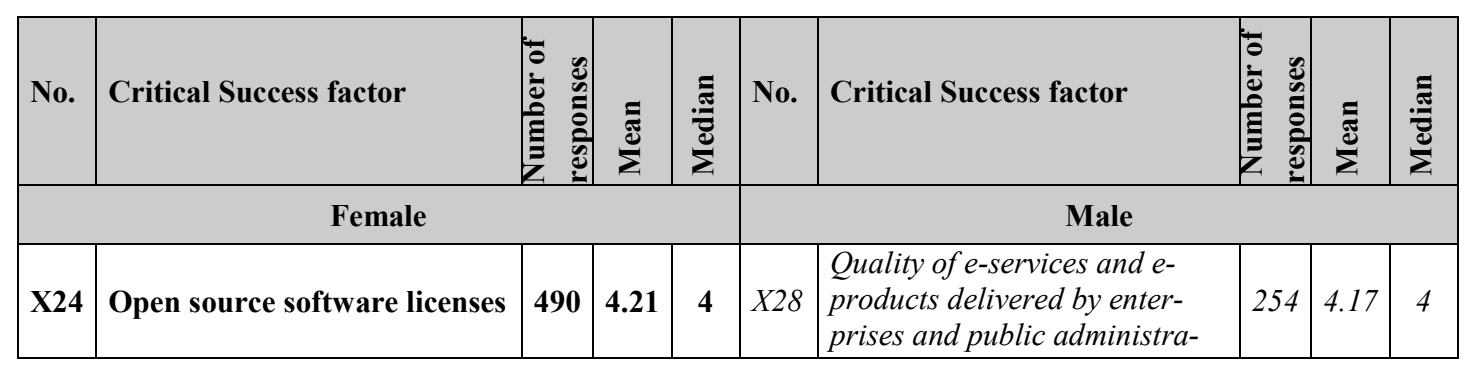

As indicated above, there are no significant differences in success factors for the adoption and usage of ICTs by males and females. Among the ten CSFs, the eight factors are the same for female and male (they are marked in bold in Table 5):

- $\mathrm{X} 8$ - Financial situation of people;

- X10 - ICT costs;

- X14 - People's awareness of ICTs;

- X22 - Technological availability of ICTs;

- X24 - Open source software licenses;

- X26 - People's competences of ICTs;

- X39- Need to make people's lives easier; and

- X40 - People's satisfaction with e-products and e-services delivered by enterprises and public administration.

The two CSFs are different for female and male. Those factors are marked in italics in Table 5.

The CSFs for the adoption and usage of ICTs within households depending on age are presented in Table 6.

Table 6: CSFs for the adoption and usage of ICTs depending on age

\begin{tabular}{|c|c|c|c|c|c|c|c|c|c|c|c|c|c|c|c|c|c|c|c|}
\hline U & 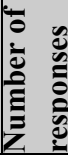 & $\sum_{\Sigma}^{\Xi}$ & 莡 & $\underset{c}{\infty}$ & 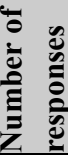 & $\sum_{\Sigma}^{\Xi}$ & 胥 & 点 & 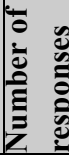 & $\stackrel{\Xi}{\Xi}$ & 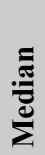 & $\underset{v}{\infty}$ & 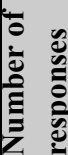 & $\stackrel{\Xi}{\Xi}$ & 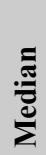 & U & 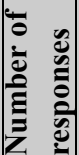 & $\sum_{\Sigma}^{\Xi}$ & 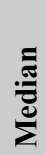 \\
\hline \multicolumn{4}{|c|}{$\begin{array}{c}<=20 \text { years old } \\
(\mathrm{Z})\end{array}$} & \multicolumn{4}{|c|}{$\begin{array}{c}\text { 21-35 years old } \\
\text { (Y) }\end{array}$} & \multicolumn{4}{|c|}{$\begin{array}{c}\text { 36-50 years old } \\
\text { (X) }\end{array}$} & \multicolumn{4}{|c|}{$\begin{array}{l}\text { 51-65 years old } \\
\text { (Baby Boomers) }\end{array}$} & \multicolumn{4}{|c|}{$\begin{array}{c}>65 \text { years old } \\
\text { (Builders) }\end{array}$} \\
\hline X8 & 99 & 4.52 & 5 & X22 & 360 & 4.47 & 5 & X39 & 150 & 4.57 & 5 & X10 & 87 & 4.61 & 5 & X22 & 21 & 4.62 & 5 \\
\hline X22 & 99 & 4.51 & 5 & $X 40$ & 359 & 4.44 & 5 & X14 & 148 & 4.46 & 5 & X22 & 87 & 4.57 & 5 & X14 & 21 & 4.48 & 5 \\
\hline X39 & 99 & 4.38 & 5 & X39 & 358 & 4.44 & 5 & X26 & 150 & 4.45 & 5 & X39 & 87 & 4.56 & 5 & X39 & 21 & 4.48 & 5 \\
\hline X10 & 99 & 4.33 & 5 & X8 & 360 & 4.38 & 5 & X22 & 149 & 4.44 & 5 & X14 & 86 & 4.49 & 5 & X26 & 21 & 4.38 & 4 \\
\hline$X 9$ & 99 & 4.24 & 4 & X10 & 360 & 4.33 & 5 & $X 40$ & 150 & 4.40 & 4 & X26 & 87 & 4.48 & 5 & $X 1$ & 21 & 4.33 & 4 \\
\hline X14 & 99 & 4.17 & 4 & $X 3$ & 358 & 4.22 & 4 & X8 & 150 & 4.37 & 5 & $X 40$ & 87 & 4.46 & 5 & X6 & 21 & 4.33 & 5 \\
\hline$X 40$ & 99 & 4.17 & 4 & X26 & 355 & 4.21 & 4 & X10 & 149 & 4.34 & 4 & X6 & 87 & 4.43 & 5 & $X 24$ & 20 & 4.25 & 5 \\
\hline$X 23$ & 98 & 4.16 & 4 & $X 24$ & 359 & 4.19 & 4 & X6 & 150 & 4.30 & 4 & X8 & 87 & 4.38 & 5 & X10 & 21 & 4.24 & 4 \\
\hline X26 & 98 & 4.13 & 4 & X14 & 359 & 4.19 & 4 & X38 & 150 & 4.27 & 4 & $X 3$ & 86 & 4.36 & 5 & X36 & 21 & 4.24 & 4 \\
\hline$X 24$ & 99 & 4.13 & 4 & $X 9$ & 358 & 4.18 & 4 & $X 29$ & 150 & 4.25 & 4 & $X 1$ & 87 & 4.33 & 5 & X8 & 21 & 4.19 & 4 \\
\hline
\end{tabular}


As indicated above, there are significant differences in success factors for the adoption and usage of ICTs by people depending on their age. Furthermore, among the ten CSFs, only six factors are the same for all generations (they are marked in bold in Table 6):

- $\mathrm{X} 8$ - Financial situation of people;

- X10 - ICT costs;

- X14 - People's awareness of ICTs;

- X22 - Technological availability of ICTs;

- X26 - People's competences of ICTs; and

- X39- Need to make people's lives easier.

The other four CSFs are very different depending on age. Those factors are marked in italics in Table 6.

The CSFs for the adoption and usage of ICTs within households depending on the level of education. are presented in Table 7.

Table 7: CSFs for the adoption and usage of ICTs depending on the level of education

\begin{tabular}{|c|c|c|c|c|c|c|c|c|c|c|}
\hline No. & Critical Success factor & 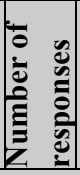 & Е & 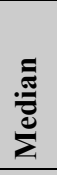 & No. & Critical Success factor & & 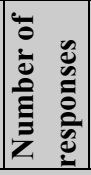 & Е & 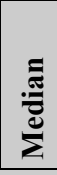 \\
\hline \multicolumn{5}{|c|}{ Secondary education } & & \multicolumn{5}{|c|}{ Higher education } \\
\hline X22 & $\begin{array}{l}\text { Technological availability of } \\
\text { ICTs }\end{array}$ & 238 & 4.45 & 5 & X39 & $\begin{array}{l}\text { Need to make people's lives } \\
\text { easier }\end{array}$ & 505 & 4.54 & 5 & 505 \\
\hline $\mathbf{X 8}$ & Financial situation of people & 238 & 4.37 & 5 & $\mathbf{X 2 2}$ & $\begin{array}{l}\text { Technological availability of } \\
\text { ICTs }\end{array}$ & 506 & 4.51 & 5 & 506 \\
\hline X39 & $\begin{array}{l}\text { Need to make people's lives } \\
\text { easier }\end{array}$ & 237 & 4.33 & 5 & $\mathbf{X 4 0}$ & $\begin{array}{l}\text { People's satisfaction with e- } \\
\text { products and e-services de- } \\
\text { livered by enterprises and } \\
\text { public administration }\end{array}$ & 506 & 4.48 & 5 & 506 \\
\hline X10 & ICT costs & 238 & 4.29 & 5 & $\mathbf{X 8}$ & Financial situation of people & 507 & 4.42 & 5 & 507 \\
\hline$x 9$ & $\begin{array}{l}\text { Economic benefits for people } \\
\text { arising from ICT adoption }\end{array}$ & 238 & 4.20 & 4 & $\mathbf{X 1 0}$ & ICT costs & 506 & 4.40 & 5 & 506 \\
\hline $\mathrm{X} 40$ & $\begin{array}{l}\text { People's satisfaction with e- } \\
\text { products and e-services deliv- } \\
\text { ered by enterprises and pub- } \\
\text { lic administration }\end{array}$ & 238 & 4.20 & 4 & $\mathrm{X} 26$ & $\begin{array}{l}\text { People's competences of } \\
\text { ICTs }\end{array}$ & 504 & 4.40 & 4 & 504 \\
\hline$X 23$ & Availability of innovative ICTs & 237 & 4.15 & 4 & X14 & People's awareness of ICTs & 503 & 4.35 & 4 & 503 \\
\hline X14 & People's awareness of ICTs & 238 & 4.14 & 4 & $X 6$ & $\begin{array}{l}\text { Public and private outlay on } \\
\text { ICT education for people }\end{array}$ & 503 & 4.27 & 4 & 503 \\
\hline X24 & Open source software licenses & 238 & 4.11 & 4 & X24 & $\begin{array}{l}\text { Open source software licens- } \\
\text { es }\end{array}$ & 505 & 4.27 & 4 & 505 \\
\hline X26 & People's competences of ICTs & 235 & 4.09 & 4 & $X 3$ & Competition on ICT market & 506 & 4.26 & 4 & 506 \\
\hline
\end{tabular}

As indicated above, there are no significant differences in success factors for the adoption and usage of ICTs depending on the level of education. Among the ten CSFs, the eight factors are the same for individuals with a higher level of education (they are marked in bold in Table 7):

- $\mathrm{X} 8$ - Financial situation of people;

- X10 - ICT costs;

- X14 - People's awareness of ICTs;

- X22 - Technological availability of ICTs; 
- X24-Open source software licenses;

- X26 - People's competences of ICTs;

- X39- Need to make people's lives easier; and

- X40 - People's satisfaction with e-products and e-services delivered by enterprises and public administration.

The two CSFs are different for people with the second and higher education. Those factors are marked in italics in Table 7.

The biggest proportion of respondents $(66.44 \%)$ were the residents of the Silesian region in Poland. Therefore, it was decided to make an analysis of CSFs for the Silesian households in comparison with households from other regions in Poland, as shown in Table 8.

Table 8: CSFs for the adoption and usage of ICTs depending on place of residence

\begin{tabular}{|c|c|c|c|c|c|c|c|c|c|}
\hline No. & Critical Success factor & 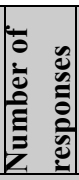 & $\sum_{\Sigma}^{\equiv}$ & 吾 & No. & Critical Success factor & 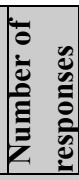 & $\sum^{\Xi}$ & 疍 \\
\hline \multicolumn{5}{|c|}{ Silesian region } & \multicolumn{5}{|c|}{ Other regions of Poland } \\
\hline $\mathrm{X} 22$ & $\begin{array}{l}\text { Technological availability of } \\
\text { ICTs }\end{array}$ & 499 & 4.45 & 5 & $\mathbf{X 3 9}$ & $\begin{array}{l}\text { Need to make people's lives } \\
\text { easier }\end{array}$ & 251 & 4.57 & 5 \\
\hline X39 & $\begin{array}{l}\text { Need to make people's lives } \\
\text { easier }\end{array}$ & 497 & 4.43 & 5 & $\mathrm{X} 22$ & $\begin{array}{l}\text { Technological availability of } \\
\text { ICTs }\end{array}$ & 251 & 4.56 & 5 \\
\hline X8 & Financial situation of people & 499 & 4.38 & 5 & $\mathrm{X} 26$ & People's competences of ICTs & 252 & 4.47 & 5 \\
\hline X40 & $\begin{array}{l}\text { People's satisfaction with e- } \\
\text { products and e-services deliv- }\end{array}$ & 498 & 4.36 & 5 & $\mathbf{X 8}$ & Financial situation of people & 252 & 4.46 & 5 \\
\hline X10 & ICT costs & 499 & 4.34 & 5 & $\mathbf{X} 40$ & $\begin{array}{l}\text { People's satisfaction with e- } \\
\text { products and e-services de- }\end{array}$ & 252 & 4.46 & 5 \\
\hline$X 9$ & $\begin{array}{l}\text { Economic benefits for people } \\
\text { arising from ICT adoption }\end{array}$ & 498 & 4.22 & 4 & $\mathbf{X 1 0}$ & ICT costs & 251 & 4.41 & 5 \\
\hline X14 & People's awareness of ICTs & 498 & 4.22 & 4 & X14 & People's awareness of ICTs & 249 & 4.41 & 5 \\
\hline$X 3$ & Competition on ICT market & 497 & 4.20 & 4 & X6 & $\begin{array}{l}\text { Public and private outlay on } \\
\text { ICT education for people }\end{array}$ & 250 & 4.38 & 5 \\
\hline X26 & People's competences of ICTs & 493 & 4.20 & 4 & $\mathrm{X} 24$ & $\begin{array}{l}\text { Open source software licens- } \\
\text { es }\end{array}$ & 251 & 4.30 & 5 \\
\hline X24 & Open source software licenses & 498 & 4.18 & 4 & $X 28$ & $\begin{array}{l}\text { Quality of e-services and e- } \\
\text { products delivered by enter- } \\
\text { prises and public administra- }\end{array}$ & 249 & 4.23 & 4 \\
\hline
\end{tabular}

As indicated above, there are no significant differences in success factors for the adoption and usage of ICTs within the Silesian households and households from other regions. Among the ten CSFs, the eight factors are the same for all Polish households (they are marked in bold in Table 8):

- X8 - Financial situation of people;

- X10 - ICT costs;

- X14-People's awareness of ICTs;

- X22 - Technological availability of ICTs;

- X24 - Open source software licenses;

- X26 - People's competences of ICTs;

- X39- Need to make people's lives easier; and

- X40 - People's satisfaction with e-products and e-services delivered by enterprises and public administration. 
The two CSFs are different for households depending on place of residence. Those factors are marked in italics in Table 8.

\section{Discussion of Findings}

The results of the current study both confirm and extend prior studies that investigated the factors affecting the adoption and usage of ICTs within households. The factors explored in the existing literature were further elaborated and new ones were identified. This study showed that factors affecting ICT adoption in Poland (and probably in the transition countries of Central and Eastern Europe) embrace factors identified based on research in well-developed and developing countries. Some of these factors are extended as summarized below.

From the standpoint of the literature reviewed within this paper, economic factors such as economic status and various funding sources (Moghaddam \& Khatoon-Abadi, 2013), household wealth (Kilenthong \& Odton, 2014), and household income (Ndung'u et al., 2012) influence the adoption and usage of ICTs. This study is consistent as economic facilitating conditions such as financial situation of individuals, ICT costs, and public outlay have significant effects on ICT adoption and usage. In addition, this study found that economic benefits for households arising from ICT adoption and usage (i.e., cost savings, time savings, savings in various materials, and greater efficiency in performing housework and professional duties) affect ICT adoption and usage. In addition, differentiation of service and product charges due to processing - electronic or traditional can encourage households to adopt and use ICTs.

Consistent with Abu-Shamaa and Abu-Shanab (2015) technological factors such as the usefulness and ease of use, and trust in online stores reveal a significant effect on ICT adoption and usage, whereas Vyas and Choudrie (2013) found that having access to the Internet and computer is a success factor of using ICTs. According to Pérez-Hernández and Sánchez-Mangas (2011), security and privacy were identified among the most important reasons for adopting and using ICTs. ICT skills were also identified as a factor determining ICT adoption and usage (King \& Boyatt, 2015). These all findings were supported by this study. In addition, these factors are extended to such ones like open source software licenses, quality of e-service and applications delivered by enterprises and public administration, and maturity of e-services delivered by enterprises and public administration. The quality of ICTs means their functionality, usability, security, compatibility, reliability, maintainability, and portability (Ziemba, 2016), whereas the maturity reflects how people can interact, communicate, and cooperate with enterprises and government units. There are five levels of e-services maturity, i.e. information, one-way interaction, two-way interaction, full electronic, and personalization (Ziemba, 2016).

The social factors like attitudes toward ICTs, incentives, interest toward adopting innovations, and ICT mentors (recommendations of ICTs) were found to encourage the adoption and usage of ICTs (e.g., Maier et al., 2011; Moghaddam \& Khatoon-Abadi, 2013; Vyas \& Choudrie, 2013; Xu $\& \mathrm{He}, 2014)$. This study is consistent with the previous research, however encouraging people to use ICTs through promotions and advertising of enterprises and public administration was stressed as an important incentive. In addition, two new factors were found. Firstly, new sociocultural competences are also necessary to achieve success in the adoption and usage of ICTs. Knowledge sharing, openness, teamwork, ability to work in cross-cultural teams, trust building, interpersonal relationship building, and also adjusting knowledge and skills to the changing labor market, education, and consumption, are all considered very important to equip people with the necessary skills to adopt and use ICTs efficiently in their day-to-day activities. Secondly, attitudes toward participation in creating and designing products and services (prosumption) influence the adoption and usage of ICTs. In various studies, demographics factors influencing ICT adoption and usage were identified, namely, age, gender, income, education, place of residence, and household composition (e.g. Choudrie et al., 2013; Dwivedi et al., 2015). This study con- 
firmed that age, household income, education, place of residence, and disability affect the adoption and usage of ICTs. In addition, this study explored whether success factors for the adoption and usage of ICTs within households are not significantly different depending on some demographic variables - the results are explained below.

The organizational adoption factors of need to make people's lives easier and people's satisfaction with e-products and e-services delivered by enterprises and public administration were found to encourage ICT usage and adoption; thereby supporting Choudrie et al., (2013). Moreover, this study found new factors affecting ICT adoption and usage. The remote performance of official duties by people, and the obligatory use of ICTs at schools, universities, workplaces, and in contact with the authorities, ensure their acceptance of and readiness for the usage of various ICTs. In addition, globalization and the possibility of purchasing, studying, or working in different places in the world very often encourage the utilization of ICTs. Furthermore, new models of education such as lifelong learning and e-learning allow people to obtain the knowledge and skills needed for the successful adoption of ICTs. Their adoption is also determined by the rule of law, especially legal regulations concerning intellectual property, digital signatures, data protection, epurchase, electoral law, and so on

In general, the proposed framework of factors affecting the adoption and usage of ICTs within households includes economic, technological, socio-cultural, and organizational factors. In addition the factors are reflected in technical and economic accessibilities of ICTs for households, ICT competences and awareness of household members, and the actual usage of ICTs within households.

According to the yielded results of the current study, it was evident that the factors for the adoption and usage of ICTs within households generally cannot be significantly different according to demographic variables. Specifically, gender, educational level, and place of residence were not able to reflect significant differences on the factors for the adoption and usage of ICTs in households in Poland. Yet, there were significant differences among the factors that could be attributed to age. Table 9 summarizes the tested hypotheses.

Table 9: Summary of hypotheses tested

\begin{tabular}{|l|l|c|}
\hline No. & \multicolumn{1}{|c|}{ Hypotheses } & Results \\
\hline H1 & $\begin{array}{l}\text { Success factors for the adoption and usage of ICTs within Polish households are not signifi- } \\
\text { cantly different depending on respondents' gender }\end{array}$ & Confirmed \\
\hline H2 & $\begin{array}{l}\text { Success factors for the adoption and usage of ICTs within Polish households are not signifi- } \\
\text { cantly different depending on respondents' age }\end{array}$ & $\begin{array}{c}\text { Unconfirme } \\
\text { d }\end{array}$ \\
\hline H3 & $\begin{array}{l}\text { Success factors for the adoption and usage of ICTs within Polish households are not signifi- } \\
\text { cantly different depending on respondents' educational level }\end{array}$ & Confirmed \\
\hline H4 & $\begin{array}{l}\text { Success factors for the adoption and usage of ICTs within Polish households are not signifi- } \\
\text { cantly different depending on respondents' place of residence }\end{array}$ & Confirmed \\
\hline
\end{tabular}

Considering the most important influence on the adoption and usage of ICTs within households in Poland ten CSFs were identified. It was found that economic status of households, cost of ICTs, and perceived economic benefits from the adoption and usage of ICTs are key factors determining ICT adoption and usage within households. Equally important are the technological issues, such as technological availability and security of ICTs, and open source software licenses. Furthermore, ICT competences and awareness, making people's lives easier, and satisfaction with the adoption and usage of ICTs are also the most influencing factors for the adoption and usage of ICTs within households in Poland.

It's worth mentioning that there are no significant differences in CSFs for the adoption and usage of ICTs within households depending on gender, educational level and place of residence of 
households' members. Among the ten CSFs, eight factors are the same for all respondents regardless of the demographics characteristics. These are:

- Financial situation of people;

- ICT costs;

- Technological availability of ICTs;

- Open source software licenses;

- People's competences of ICTs;

- People's awareness of ICTs;

- Need to make people's lives easier; and

- People's satisfaction with e-products and e-services delivered by enterprises and public administration.

The six of those above factors are the same within households depending on age of households' members. Among the ten CSFs, only six factors are the same for all generations, i.e.:

- Financial situation of people;

- ICT costs;

- Technological availability of ICTs;

- People's competences of ICTs;

- People's awareness of ICTs; and

- Need to make people's lives easier.

The other factors that were different depending on the demographics characteristics of households' members are as follows:

- Public outlay on hardware, networks, and telecommunications;

- Public and private outlay on ICT education for people;

- Competition on ICT market;

- Economic benefits for people arising from ICT adoption;

- Availability of innovative ICTs

- Quality of e-services and e-products delivered by enterprises and public administration

- ICT security;

- New model of education; and

- Obligatory ICT usage at schools, universities, workplaces, in contacts with authorities.

In summary, the framework of CSFs influencing the adoption and usage of ICTs within households are presented in Figure 1.

CSFs are important and noteworthy because they give a good basis for stating which determinants should be followed and which barriers removed for the adoption and usage of ICTs in households. All these factors delineate crucial areas that should require a primary focus in order to achieve the most satisfying results of ICT adoption and usage. Consequently, the factors act primarily to spur the strategic and operational activities of governments and enterprises favoring the adoption and usage ICTs within households.

As mentioned above, there are some differences in ICT adoption between developed and European transition economies (Roztocki \& Weistroffer, 2011; Soja \& Cunha, 2015). However, this study helps provide some insights that can lead to improved adoption and usage of ICTs in Poland and other transition countries of Central and Eastern Europe. This is because those countries are similar and they have to resolve the same problem. They are similar not only through their common neighborhoods and analogous geopolitical situation, but also through their joint history, traditions, culture and values. There is also a similarity in the field of building democratic state 
structures and a free-market economy as well as participating in the European integration process. The quality of ICT and telecommunication infrastructure in the Central and Eastern Europe countries is at the similar level. These countries have to overcome the same political, economic, social, technological and other barriers in their transition from the centrally planned economy to a freemarket economy, also from an industrial society to an information society driven by the use of ICTs and information.

\section{Economic factors}

- Financial situation of people

- ICT costs

- Competition on ICT market

- Public and private outlay on ICT education for people

- Public outlay on hardware, networks, and telecommunications

- Economic benefits for people arising from ICT adoption

\section{Technological factors}

- Technological availability of ICTs

- Availability of innovative ICTs

- Open source software licenses

- Quality of e-services and e-products delivered by enterprises and public administration

- ICT security

\section{CSFs for adoption and usage of ICTS within households \\ Organizational factors \\ - Need to make people's lives easier \\ - People's satisfaction with e-products and e-services deliv- ered by enterprises and public administration \\ - New model of education \\ - Obligatory ICT usage at schools, universities, workplaces, in contacts with authorities \\ Socio-cultural factors \\ - People's competences of ICTs \\ - People's awareness of ICTs}

Figure 1: CSFs affecting the adoption and usage of ICTs within households

\section{Conclusion}

\section{Research Contribution}

This research contributes to the literature on the information society, especially the adoption and usage of ICTs within households. The main contribution is to provide a comprehensive view on the factors affecting the adoption and usage of ICTs within households. Here, previous knowledge is extended by the fact that the factors are analyzed and synthesized from various dimensions and in the context of emerging trends of the information society. Furthermore, knowledge from conducting studies on factors affecting the adoption and usage of ICTs within households is enhanced by providing the methodology for examining factors.

From a practical point of view, the results of this study are highly relevant for all stakeholders of the information society, not only people but mainly governments and enterprises. Their knowledge is increased by employment of the proposed methodology and framework of factors to identify areas in which satisfactory results will ensure the successful adoption and usage of ICTs within households.

\section{Implication for Research and Practice}

This study can be useful for researchers. They may use this methodology and do similar analyses with different sample groups in other countries, and many comparisons between different countries can be made. Moreover, the methodology constitutes a very comprehensive basis for identi- 
fying success factors for the adoption and usage of ICTs within households, but researchers may develop, verify, and improve this methodology and its implementation.

The result of the study is beneficial to various related stakeholders within society. Both, policy makers and ICT providers can benefit from the findings with regard to bridging the gap of ICT adoption and use in the country. The identified factors are not unique only to Poland. They should be definitely useful for developing and emerging countries, especially the transition countries of Central and Eastern Europe. Knowledge about the factors impacting the adoption and usage of ICTs within households could help governments to develop sound ICT projects and receive funding from the European Union. Enterprises and government units could find ideas on developing and enhancing ICTs, e-services, and e-products for households.

\section{Limitation and Future Research}

As with many other studies, this study has its limitations. The sample only included Polish households. Caution should be taken when generalizing our findings to other countries. Another limitation is that there is only the viewpoint of households. However, some factors are related to other information society stakeholders, i.e., enterprises and public administration. Employing a snapshot research approach in this study is another limitation since the data was collected for the first time. To capture the dynamics of success factors, future longitudinal research may be necessary.

\section{Acknowledgement}

This research has been supported by two grants: (1) "Designing a system approach to sustainable development of the information society - on the example of Poland" from the National Science Centre in Poland, 2011/01/B/HS4/00974, 2011-2015; and (2) "Transformation of business and public administration by information technology and information systems" from the University of Economics in Katowice, Poland, 2014-2016.

\section{References}

Abu-Shamaa, R., \& Abu-Shanab, E. (2015) Factors influencing the intention to buy from online stores: An empirical study in Jordan. In Proceedings of the 8th IEEE GCC Conference and Exhibition, Muscat, Oman, February 1-4.

Berleur, J., Hercheui M. D., \& Hilty L. M. (Eds.) (2010). What kind of information society? Governance, virtuality, surveillance, sustainability, resilience. Brisbane: IFIP.

Boughzala, I., Janssen, M., \& Assar, S. (2014). Case studies in e-government 2.0 - Changing citizen relationships. New York: Springer.

Chmielarz, W., \& Zborowski M. (2013). Conversion method in comparative analysis of e-banking services in Poland. Lecture Notes in Business Information Processing, 158, 227-240.

Choudrie, J., Vyas, A., Voros, T., \& Tsitsianis, N. (2013). Comparing the adopters and non-adopters of online social networks: A UK perspective. In Proceedings of 46th Hawaii International Conference on System Sciences, Wailea, Maui, USA, January 7-10, 2013.

Dennis, A. R., Samuel, B., \& McNamara, K. (2014). Design for maintenance: How KMS document linking decisions affect maintenance effort and use. Journal of Information Technology, 29, 312-326, DOI: $10.1057 /$ jit.2014.5

Dwivedi, Y. K., AlAlwan, A. A., Rana, N., \& Williams, M. D. (2015). Jordanian customers' intention towards and use of Internet banking: Exploring demographic differences on their perception. In Proceedings of United Kingdom Academy of Information Systems International Conference UKAIS. Oxford: Oxford University. 
Elliot, S. (2011). Transdisciplinary perspectives on environmental sustainability: a resource base and framework for IT-enabled business transformation. MIS Quarterly, 35(1), 197-236.

Eurostat. (2015). Information society statistics. Retrieved from: http://ec.europa.eu/eurostat/web/information-society/data/main-tables

Ferro, E., Dwivedi, Y. K., Gil-Garcia, J. R., \& Williams, M. D. (Eds.). (2010). Handbook of research on overcoming digital divides: Constructing an equitable and competitive information society. Hershey: IGI Global.

Fuchs, C. (2009a). Sustainable information society as ideology (part I). Informacios Tarsadalom, 9(2), 719.

Fuchs, C. (2009b). Sustainable information society as ideology (part II). Informacios Tarsadalom, 9(3), 2752 .

Gil-Garcia, J.R. (Ed.). (2012). Enacting electronic government success: An integrative study of government-wide websites, organizational capabilities, and institutions. New York: Springer.

Goliński, M. (2011). Spoleczeństwo informacyjne. Geneza koncepcji i problematyka pomiaru [Information society. Genesis and measurement issues]. Warsaw: Oficyna Wydawnicza Szkoły Głównej Handlowej.

Grudzewski, W. M., Hejduk, K. I., Sankowska, A., \& Wańtuchowicz, M. (2010). Sustainability w biznesie, czyli przedsiębiorstwo przyszłości. Zmiany paradygmatów i koncepcji zarzadzania [Sustainability in business - future enterprise. New management paradigms and concepts].Warszawa: Poltext.

Hamid, S., Waycott, J., Kurnia, S., \& Chang, S. (2015). Understanding students' perceptions of the benefits of online social networking use for teaching and learning. Internet and Higher Education, 26, 1-9.

Hilty, L. M. (2008). Information technology and sustainability: Essays on the relationship between information technology and sustainable development. Norderstedt: Empa.

Hilty, L. M. (2009). Environmental informatics and the vision of a sustainable information society. Informacios Tarsadalom, 9(3), 6-15.

Huang, Z., \& Benyoucef, M. (2013). From e-commerce to social commerce: A close look at design features. Electronic Commerce Research and Applications, 12(4), 246-259.

Ifinedo, P., \& Singh, M. (2011).Determinants of eGovernment maturity in the transition economies of Central and Eastern Europe. Electronic Journal of e-Government, 9(2), 166-182.

Kesharwani, A., \& Bisht, S. S. (2012). The impact of trust and perceived risk on internet banking adoption in India: An extension of technology acceptance model. International Journal of Bank Marketing, 30(4), 303-322.

Kilenthong, W. T., \& Odton, P. (2014). Access to ICT in rural and urban Thailand. Telecommunications Policy, 38, 1146-1159.

King, E., \& Boyatt, R. (2015). Exploring factors that influence adoption of e-learning within higher education. British Journal of Educational Technology, 46(6), 1272-1280. DOI: 10.1111/bjet.12195

Koohang, A., Kohun, F. G., \& DeLorenzo, G. (2013). Knowledge construction through active learning in elearning: An empirical study. Journal of Applied Knowledge Management, 1(1), 18-28.

Kowalczyk, A., \& Nogalski, B. (2007). Zarzadzanie wiedza. Koncepcja i narzędzia [Knowledge management. Concepts and tools]. Warsaw: Difin.

Liu, P. L. (2011). Empirical study on influence of critical success factors on ERP knowledge management on management performance in high-tech industries in Taiwan. Expert Systems with Applications, 38(8), 10696-10704.

Luo, X., Lu, Y., Polgar, M., \& Cao, Y. (2010). Social network analysis of a criminal hacker community. Journal of Computer Information Systems, 51(2), 31-41. 
Maier, C., Laumer, S., \& Eckhardt, A. (2011). Technology adoption by elderly people - An empirical analysis of adopters and non-adopters of social networking sites. In Proceedings of 10th International Conference on Wirtschaftsinformatik, Zurich, Switzerland, February 16-18, 2011.

McCrindle, M. (2014). The ABC of XYZ. Understanding of global generations. Bella Vista: McCrindle Research.

Melville, N. (2010). Information systems innovation for environmental sustainability. MIS Quarterly, $34(1), 1-21$.

Moghaddam, B.K., \& Khatoon-Abadi, A.K. (2013). Factors affecting ICT adoption among rural users: A case study of ICT center in Iran. Telecommunications Policy, 37, 1083-1094.

Ndung'u, M. N., Mwololo, T., \& Mitullah, W. V. (2012). Factors influencing usage of new technologies in low-income households in Kenya: The case of Nairobi. Info, 14(4), 52-64.

Niehaves, B., \& Plattfaut, R. (2011). The MATH of Internet adoption: Comparing different age-groups. In Proceedings of 10th International Conference on Wirtschaftsinformatik, Zurich, Switzerland, February 16-18, 2011.

Nulty, D. D. (2008). The adequacy of response rates to online and paper surveys: what can be done? Assessment \& Evaluation in Higher Education, 33(3), 301-314. DOI: 10.1080/02602930701293231

Olla, P., \& Choudrie, J. (2013). Mobile technology utilization for social development in developing countries: An ethnographic futures research study. Information Systems Frontiers, 16(3), 369-382. DOI: $10.1007 / \mathrm{s} 10796-013-9477-y$

Olszak, C. M., \& Ziemba, E. (2012). Critical success factors for implementing business intelligence systems in small and medium enterprises on the example of Upper Silesia, Poland. Interdisciplinary Journal of Information, Knowledge, and Management, 7, 129-150. Retrieved from http://www.informingscience.org/Publications/1584

Pérez-Hernández, J., \& Sánchez-Mangas, R. (2011). To have or not to have Internet at home: Implications for online shopping. Information Economics and Policy, 23, 213-226.

Raban, D. R., Gordon, A., \& Geifman, D. (2011). The information society. The development of a scientific specialty. Information, Communication \& Society, 14(3), 375-399.

Rana, N P., Dwivedi, Y. K., \& Williams, M. D. (2013). Analysing challenges, barriers and CSF of egov adoption. Transforming Government: People, Process and Policy, 7(2), 177-198.

Rockart, J. F. (1979). Chief executives define their own data needs. Harvard Business Review, 57(2), 8193.

Roztocki, N., \& Weistroffer, H. R. (2011). Information technology success factors and models in developing and emerging economies. Information Technology for Development, 17(3), 163-167.

Schauer, T. (2003). The sustainable information society - Vision and risks. Vienna: The Club of Rome, European Support Centre.

Servaes, J., \& Carpentier, N. (Eds.). (2006). Towards a sustainable information society. Deconstructing WSIS. Portland: Intellect.

Soja, P. (2010). Understanding determinants of enterprise system adoption success: Lessons learned from full-scope projects in manufacturing companies. Production Planning \& Control, 21(8), 736-750.

Soja, P., \& Cunha, P. R. (2015). ICT in transition economies: Narrowing the research gap to developed countries. Information Technology for Development, 21(3), 323-329,

Steyn, J., \& Johanson, G. (Eds.). (2010). ICTs and sustainable solutions for the digital divide: Theory and perspectives. Hershey: Idea Group.

Stork, C., Calandro, E., \& Gillwald, A. (2013). Internet going mobile: Internet access and use in 11 African countries. Info, 15(5), 34-51. 
Tapscott, D., \& Williams, A. D. (2012). Macrowikinomics: Rebooting business and the world. New York: Penguin.

Tarhini, A., Hone, K., \& Liu, X. (2016). Examining the moderating effect of individual-level cultural values on users' acceptance of e-learning in developing countries: A structural equation modeling of an extended technology acceptance model. Interactive Learning Environment, 1-22. Retrieved from http://dx.doi.org/10.1080/10494820.2015.1122635

Vyas, A., \& Choudrie, J. (2013). Online social networking in older individuals: A study of Hertfordshire. In Proceedings of Twenty-First European Conference on Information Systems ECIS, Utrecht, Belgium, June 5-8, 2013.

Webster, F. (2002). Theories of the information society. New York: Routledge.

$\mathrm{Xu}, \mathrm{W} .$, \& He, Y. (2014). An empirical study on influencing factors of e-learning behavior in an enterprise knowledge community. In D. Zheng \& L. Zhang (Eds.), Future computer and information technology. Southampton: WIT Press, 83-92.

Yang, S., Y. Chen, \&Wei, J. (2015). Understanding consumers' web-mobile shopping extension behavior: A trust transfer perspective. Journal of Computer Information Systems, 55(2), 77-87.

Yeoh, W., \& Koronios, A. (2010). Critical success factors for business intelligence systems. Journal of Computer Information Systems, 50(3), 23-32.

Ziemba, E. (2013). The holistic and systems approach to a sustainable information society. Journal of Computer Information Systems, 54(1), 106-116.

Ziemba, E. (Ed.). (2015a). Czynniki sukcesu i poziom wykorzystania technologii informacyjnokomunikacyjnych $w$ Polsce [Success factors for and level of adopting ICT in Poland]. Warsaw: CeDeWu.

Ziemba, E. (2015b). Examining critical success factors for sustainable information society - Lessons learned from Poland. In Proceedings of Twenty-Third European Conference on Information Systems ECIS, Münster, Germany, May 27-29, 2015.

Ziemba, E. (Ed.). (2016). Towards a sustainable information society: People, business and public administration perspectives. Newcastle upon Tyne: Cambridge Scholars Publishing.

Ziemba, E., \& Papaj, T. (2013). A pragmatic approach to the e-government maturity in Poland - Implementation and usage of SEKAP. In Proceedings of European Conference on eGovernment ECEG, University of Insubria, Como, Italy, June 13-14, 2013, 560-570.

Ziemba, E., Papaj, T., Żelazny, R., \& Jadamus-Hacura, M. (2015). Building and evaluating classification framework of critical success factors for e-government adoption. In Proceedings of European Conference on eGovernment ECEG, University of Portsmouth, Portsmouth, UK, June 18-19, 2015, 341-350.

\section{Biography}

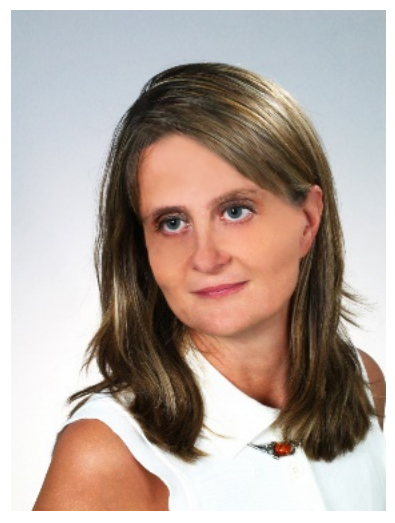

Ewa Ziemba completed her Ph.D. and Post Ph.D. in Management, with a major focus on management information systems. She is an Associate Professor at the University of Economics in Katowice, Poland. Her current research focuses on information systems and technologies for business and public administration transformation. She has published over 170 peerreviewed papers and 16 books, and has played an instrumental role in prestigious Polish and international research projects. Ewa Ziemba serves on the editorial boards of several international journals, e.g. she is the editor of Interdisciplinary Journal of Information, Knowledge, and Management; Interdisciplinary Journal of e-Skills and Lifelong Learning. She is the Founding Editor-in-Chief of The Online Journal of Applied Knowledge Management. She is also the Vice President for Research Collaborations of the International Institute for Applied Knowledge 
Management. Ewa Ziemba has received numerous awards for research and teaching, including The Excellent Award of the President of the University of Economics in Katowice, The Silver Cross of Merit from the President of Poland, The Medal of the National Education Commission from the Ministry of National Education in Poland, and The Award of Fellow \& Distinguished Scholar from the International Institute for Applied Knowledge Management, and several The Best Papers awards, also at the Informing Science \& IT Education Conferences. 